\title{
Reasons for IPO Implementation: Empirical Evidence from the Polish Capital Market
}

\author{
Tomas Meluzin, Marek Zinecker
}

Brno University of Technology

Kolejni 2906/4, CZ-61200, Brno, Czech Republic

E-mail: meluzint@fbm.vutbr.cz, zinecker@fbm.vutbr.cz

cross $^{\text {ref }}$ http://dx.doi.org/10.5755/j01.ee.25.3.3529

\begin{abstract}
This paper examines determinants influencing the decision to go public by enterprises under the conditions in force on the Polish capital market. The intent of this research required to collect primary data. The sample has been divided into two groups. The first group consisted of the entities that have previously executed an initial public offering (IPO), the second one included the entities that considered doing so in the past or are IPO candidates. The survey results can be summarized as follows. First, raising external capital as a reason for IPO received a strong support from the respondents of both groups of companies. Next, more than $50 \%$ of respondents in each group believe that IPO will have a positive effect on its image and publicity. Most of the respondents also believe that IPO will improve the company valuation, strengthen the management's bargaining position in negotiations with providers of external capital, and increase the attractiveness of the company as an employer. Thirdly, the respondents do not see debt reduction as a reason to go public. Low level of support was given to other reasons, which include withdrawal from the venture capital fund, diversification of the existing shareholders' portfolios, and solution to the succession problem. The results of this survey made it possible to formulate new insights as contributions towards a better understanding of corporate financing strategies under the specific conditions of the CEE region.
\end{abstract}

Keywords: Corporate Finance, Financial Decisions, IPO, Initial Public Offering, Capital Market, Poland.

\section{Introduction}

Capital structure and factors influencing it in different countries as well as different business sectors have been analyzed in many empirical studies. Referring to Norvaisiene (2012), there is a fair amount of such studies done in the developed countries, and recently it is becoming a very popular area of research in developing countries as well. The major issues considered by many researchers include (Norvaisiene, 2012): What is the impact of debt capital on growth opportunities of companies? What is the impact of capital structure decisions on investments and value of a company? What is the impact of financing decisions on performance efficiency of companies, in particular on profitability indicators?

Corporate finance draws capital from equity and debt. The study carried out by Chen \& Liou \& Huang (2012) emphasizes that it is widely believed that in a world with imperfections, such as, bankruptcy costs, agency cost, and benefits from leverage-induced tax shields, associated with drawing debts, an optimal capital structure for the project may exist. Specifically, the amount of debt and equity affect the cost of capital and, therefore, the project's financial viability.

The rationale of obtaining external equity capital is well supported in earlier works, such as those of (Modigliani \& Miller, 1958, 1963; Scott, 1976; Myers, 1984). These authors state that there is an optimal capital structure and companies act as necessary to achieve it. They have a natural preference for the cheapest source of financing and resort to a more expensive source only upon exhausting the cheap one.

The past decade has witnessed a worldwide rise in the importance of financing corporate growth through "Initial Public Offering of Securities" (IPO). The theory of corporate finance regards IPO implementation strategy as one of the most important decisive junctures in the life of a company (Helwege \& Packer, 2003; Brau \& Francis \& Kohers, 2003; Boehmer \& Ljungqvist, 2004). Most empirical IPO research examines the following seven issues (Brau \& Fawcett, 2006): the reasons and motivations for going public, timing of IPO, underwriter selection, underpricing, signalling, IPO process issues, and the decision to stay private.

The studies carried out by (Chemmanur \& Fulghieri, 1999; Ritter \& Welch, 2002; Paleari et al., 2006) concluded that there were three fundamental reasons to conduct an IPO. These were: obtaining external equity capital to fund company growth, enhancing company's image, and gaining advantages for the shareholders.

Raising funds through an IPO should be an alternative to borrowing, particularly in companies with high investments (now or in the foreseeable future), high proportion of debt in the capital structure, and high potential for growth. All of these factors, according to Panetta et al., (1998), motivate companies to enter the capital market via an IPO.

Paleari et al., (2006) state that initial public offering constitutes an extraordinary financial transaction by means of which the company can improve its liquidity and the capital structure. The balance sheet of those businesses that 
seek capital through public share offerings typically has a larger equity, that is a lower level of indebtedness. This reduces the likelihood of bankruptcy when operating at a loss (say in a period of economic recession).

(Pagano, 1993; Black \& Gilson, 1998) discuss another reason to execute IPO, which is to provide a benefit to the existing shareholders, for whom it is easier to sell their shares of stock if they are publicly traded on a capital market. This allows the shareholders to be more flexible in their financial activities. At the same time, the payments made on this market have no effect on the financial situation of the issuing company. Raising the basic capital through a public issue also eliminates the difference between the large shareholders, who tend to take a longterm approach to investing, and the small ones, who value liquidity and are therefore inclined to take a short-term view of their investment. A frequent reason for IPO is the majority shareholder's desire to reduce his stake in the company. In some cases, IPO will resolve the problem of generational succession in a family-run enterprise. From the shareholder's perspective, the option to cash out his coownership by selling the shares of stock at any time on the secondary market is an advantage that imparts a great deal of flexibility to his financial decisions (Black \& Gilson, 1998; Mello \& Pardone, 1998).

Initial public offering can also be an exit strategy for venture capital funds, and a way to realize profits on investments (Black \& Gilson, 1998; Mello \& Pardone, 1998).

The last reason, usually subordinate to the previous two, is to gain a non-financial advantage from IPO implementation, such as the greater attention that the media pay to publicly traded companies. Maksimovic \&
(Pichler, 2001; Jezek, 2004) also mention some positive effects associated with IPOs in the area of marketing.

A company that issues IPO is usually motivated by a combination of several above-mentioned reasons. The companies often choose this form of financing to raise the necessary capital and respond to the need of some existing shareholders (possibly the venture capitalists) who wish to liquidate their stake in the company through IPO.

The foregoing review of literature makes it clear that the research into what motivates companies to go public has a tradition going back many years in advanced market economies. According to (Brau \& Fawcett, 2006), most empirical IPO research relies on the publicly available stock return data, or the data contained in the Securities and Exchange Commission (SEC) filings. (Brau \& Fawcett, 2006) enriched the IPO literature with analyses of original data from the surveys of Chief Financial Officers (CFOs), whose perceptions they compared with the prevailing academic theory.

The question that remains unanswered is whether the academic theories formulated for well developed capital markets apply also to decision-making about IPOs in enterprises operating on capital markets in the region of Central and Eastern Europe (CEE). Under the conditions of emerging capital markets in the CEE countries, both theory and corporate practice grapple with the absence of empirical results.

The largest capital market of the Central and Eastern European countries is the Polish one. Poland has the only capital market in the CEE region that lends itself to empirical surveys. The number of IPOs issued on the capital markets of the Visegrad Four countries in the years 1998-2011 is shown in Table 1.

Number of IPOs on the Visegrad Four Capital Markets in 1998-2011 (Paleari et al., 2008, 2009, 2010)

Table 1

\begin{tabular}{|l|r|r|r|r|r|r|r|r|r|r|}
\hline STOCK EXCHANGE & $\mathbf{2 0 0 2}$ & $\mathbf{2 0 0 3}$ & $\mathbf{2 0 0 4}$ & $\mathbf{2 0 0 5}$ & $\mathbf{2 0 0 6}$ & $\mathbf{2 0 0 7}$ & $\mathbf{2 0 0 8}$ & $\mathbf{2 0 0 9}$ & $\mathbf{2 0 1 0}$ & $\mathbf{2 0 1 1}$ \\
\hline Warsaw Stock Exchange & 5 & 6 & 36 & 34 & 35 & 68 & 29 & 10 & 22 & 20 \\
\hline Prague Stock Exchange & 0 & 0 & 1 & 0 & 2 & 1 & 1 & 0 & 0 & 1 \\
\hline Budapest Stock Exchange & 0 & 0 & 1 & 0 & 3 & 0 & 1 & 2 & 1 & 5 \\
\hline Bratislava Stock Exchange & 1 & 0 & 0 & 0 & 0 & 0 & 0 & 0 & 0 & 0 \\
\hline Ljubljana Stock Exchange & 0 & 0 & 0 & 0 & 2 & 1 & 1 & 0 & 0 & 1 \\
\hline Total & $\mathbf{6}$ & $\mathbf{6}$ & $\mathbf{3 8}$ & $\mathbf{3 4}$ & $\mathbf{4 2}$ & $\mathbf{7 0}$ & $\mathbf{3 1}$ & $\mathbf{1 2}$ & $\mathbf{2 3}$ & $\mathbf{2 7}$ \\
\hline
\end{tabular}

The novelty of this study is the focus on the analysis of factors that influence the decision for going public under conditions of the Polish capital market, which has been considered as the most important one among the CEE countries. The purpose of this article is to explore the factors that influence the decision of enterprises to go public in Polish capital market and thus to enlarge the current IPO literature with an analysis of responses from a survey that posed the following question: What are the key motives of companies in Poland to go public?

The object of the survey covers the assessment of motivations for conducting IPO for a sample of companies operating on the Polish capital market.

This paper is divided into four sections. The introductory section is followed by section 2, which describes the methodology and the sources of data used in the study. Its findings are analyzed in section 3. Finally, section 4 discusses the results and conclusions.

\section{Survey Methodology and Data Sources}

The research approach was developed after an extensive review of IPO-oriented academic literature (Brau \& Fawcett, 2006; Snieska \& Venckuviene, 2011). Research methods cover the comparative analysis of scientific literature documents and reports as well as statistic data. Moreover, the intent of this research required to collect primary data. The sample consists of two types of companies, which means that we study two subsamples. The first subsample consists of the entities that have previously executed an initial public offering of shares on the Polish capital market (Subsample A - Successful). The second subsample includes the entities that have not executed IPO, but considered doing so in the past or were candidates for doing it in the future (Subsample B - Not Tried). 
The questionnaire itself, in the Polish language, consisted of two parts: the reasons to conduct IPO, and the reasons to retain private ownership.

The basic Group A was composed of companies that had entered the Main Market of Warsaw Stock Exchange through IPO in the years 2007-2009. The time limitation on the entry into the capital market was necessary to ensure that the research data would come from corporate officers who had been personally involved in a recent IPO process. This group of respondents was drawn from the data published on the Warsaw Stock Exchange website (www.gpw.pl) and the publications of Paleari et al., (2007, 2008, 2009). The entire list contained 107 companies, or possibly their CFOs or Chairmen of the Board of Directors.

It is difficult to estimate how large is the group of companies that have not entered the capital market through IPO but considered doing so in the past or are poised for a future filing. Nonetheless, a database of 60 companies (potential IPO candidates) was compiled from the information provided by brokers who had the experience of implementing IPOs on the Polish capital market.

The data were collected in two main stages. In early 2010, the questionnaire accompanied by a personalized and signed cover letter was sent to all A-type companies on the survey list. To increase the return rate, the questionnaire was put into an electronic form and, in April 2010 , sent by e-mail to the individuals who had not replied the first time around, with a request for completion. Overall, 21 CFOs submitted usable answers (i.e. the response rate is $19,6 \%$ ).

In the fall of 2011, the questionnaire with a cover letter was sent to all 60 companies in Group B. Again, to boost the return rate, a second request for participation in the survey was e-mailed to all respondents in January 2012. In the end, 18 completed questionnaires were received, which represents a $30 \%$ response rate.

It should be pointed out that the return rates fall within the range mentioned in other survey-based financial studies (Brau \& Fawcett, 2006). The questionnaire-collected data were treated by statistical methods reflecting their nature and quantity. Descriptive methods served as the basic statistical analyses. Categorical data were processed using contingency tables and evaluated by the $\mathrm{M}-\mathrm{V}$ chi-square test corrected for small frequency in individual categories. Mann-Whitney's U-test was applied to compare the statistical data between monitored groups. The data were evaluated at the significance level of $\alpha=5 \%$. The entire statistical evaluation was performed by Statistica software, version 10 .

\section{Survey Results}

Tables 2 and 3 summarize the results of descriptive statistics separately for both monitored group of companies (A and B). Table 4 presents the descriptive statistics derived from all companies as one set of observations, with a subsequent comparison of the two sets of statistical data using the Mann-Whitney U-test.

\section{Descriptive Data Analysis}

The respondents were asked to indicate, on a fivepoint scale (1-unimportant, 5-very important), "how important were/are the following reasons for conducting an IPO?" The results of this analysis are expressed as an arithmetic mean \pm standard deviation followed by the relative frequency of answers 4 and 5 .

The research results (Table 4) for an all-inclusive set of respondents (companies A plus B) indicate that the companies view the raising of own external capital for developmental investments as the main reason to execute IPO (overall: 4,67 $\pm 0,62 ; 92,31 \%$ ). This reason corresponds to other valid reasons for bringing the company onto a public capital market. Most respondents from both groups of companies expect that IPO will have a positive impact on the issuer's image and publicity (overall: $3,82 \pm 1,14 ; 64,10 \%)$, and that the trading of shares on a public capital market will prove useful in company valuation (overall: $3,68 \pm 0,96 ; 61,54 \%$ ). Other significant reasons to launch IPO are to strengthen the company's bargaining position in dealing with the sources of external capital (overall: $3.49 \pm 0.97 ; 53,85 \%$ ), and to enhance the attractiveness of the company as an employer (overall: 3.44 $\pm 1,10 ; 51,28 \%)$. Almost half of the respondents also believe that the public trading of shares could be advantageous in future mergers and acquisitions (overall: $3,36 \pm 1,14 ; 48,72 \%$ ), and that IPO will lower the cost of capital for the company (overall: $3,21 \pm 1,12 ; 43,59 \%$ ).

In addition, Tables 2 and 3 permit to examine the research results for both groups of companies, first separately and then in comparison. It is obvious that the raising of external capital is the reason of comparable importance for a great majority of respondents in both monitored groups of companies (A: 4,86 $\pm 0,48 ; 95,24 \%$; B: $4,44 \pm 0,70 ; 88,89 \%)$. For most companies, another similarly important reason to enter the capital market is a greater publicity and image enhancement (A: $4.00 \pm 1.10$; $66,67 \%$; B: $3,61 \pm 1.20 ; 61,11 \%)$. Almost $62 \%$ of the respondents in Group A of companies and almost $65 \%$ of the respondents in Group B acknowledge that a significant reason to join a stock exchange is the advantage of publicly traded shares in assessing the market value of a company (A: 3,71 $\pm 1,06 ; 61,91 \%$; B: 3,65 $\pm 0,86 ; 64,71 \%$ ).

Looking at the relative importance of other reasons for IPO, it is possible to detect certain differences between the two monitored groups of companies. The respondents in Group A of companies emphasize the usefulness of publicly traded shares for future mergers and acquisitions. Conversely, the majority of respondents in Group B of companies consider that reason to be less significant (A: $3,81 \pm 1,08 ; 76,19 \% ; \mathrm{B}: 2,83 \pm 0,99 ; 16,67 \%)$. More than half of the respondents in Group A also think that IPO is a suitable manner to strengthen the company's bargaining position in negotiating with providers of external capital (A: 3,71 $\pm 1,10 ; 66,67 \%$; B: $3.22 \pm 0,73 ; 38,89 \%$ ), and that initial public offering enhances the attractiveness of the company as an employer (A: $3.71 \pm 1,06 ; 61,91 \%$; B: $3,11 \pm 1,08 ; 38,89 \%)$. Slight differences between the studied groups of companies may be seen in their perception of IPO's importance in reducing the cost of capital. While more than $50 \%$ of Group B respondents consider lowering the cost of capital to be a strong reason for initial offering, only $38 \%$ of respondents in Group A consider that reason to be very significant $(\mathrm{A}: 3,05 \pm 1,24$; $38,10 \%$; B: $3,41 \pm 0,94 ; 52,94 \%)$. 
With regard to the less significant reasons that affect IPO decisions, there is a relatively good agreement between the two groups of companies. According to the respondents from all companies, as well as their respective groups, the following reasons are not good enough to justify a company's entry into the stock market: solving the problem of succession (A: 1,38 $\pm 0,67$ and $0,00 \%$; B: 1,88 $\pm 1,23$; $11,11 \%$ ), withdrawal from a venture capital fund (A: 1,95 \pm 1,$56 ; 19,05 \%$; B: $2,38 \pm 1,20 ; 27,78 \%$ ), diversification of stock portfolio of current shareholders (A: $2.76 \pm 1,41$; $33,33 \% ; \mathrm{B}: 2,33 \pm 1.03 ; 16,67 \%)$, and reduction of the company's indebtedness (A: 2,38 $\pm 1,40 ; 19,05 \%$; B: 3,00 \pm $0,77 ; 27,78 \%)$. It is therefore obvious that most companies do not perceive IPO as a tool to reduce the direct indebtedness, but as a way to strengthen the bargaining position in dealing with sources of external capital.

\section{Comparison of Motives Between the Subsamples}

Further treatment of data sought to determine if statistically significant differences exist in the frequency of respondents' answers within the studied groups of companies (Group A - IPO companies, and Group B - Not Tried). The comparison was done by applying two tests: $\mathrm{M}-\mathrm{V}$ chi-square test (analysis of categorical data) and Mann-Whitney U-test (analysis of continuous data).
The results of the M-V chi-square test and MannWhitney U-test both indicated a statistically significant difference in the frequency of responses to "the use of publicly traded shares for later mergers and acquisitions" $\left(\chi^{2}=15,86 ; \mathrm{df}=2 ; \mathrm{p}<0,001\right)$. Statistically significant difference was the outcome of a non-parametric test (Mann-Whitney U-test), which is based on the order of values, not on the values obtained by measurement. Statistically significant difference is evident from the mode frequency and the standard deviation values (Group A versus Group B exhibits a higher mode frequency and a lower standard deviation, therefore Group A has a lower data variability).

The results of the Mann-Whitney U-Test (Table 4) also identified statistically significant differences between the two groups of companies in connection with two other reasons to execute IPO, which were not confirmed by the $\mathrm{M}-\mathrm{V}$ chi-square test, namely the company debt reduction $(\mathrm{p}=0.048)$ and the use of publicly traded shares for future mergers and acquisitions ( $\mathrm{p}=0,003)$.

The difference in the results is caused by the lower sensitivity of the M-V chi-square test and the conversion of data from continuous to categorical, which lowers the data variability.

Survey Results - Reasons for Conducting IPO (Subsample A)

Means are based on a five-point scale ranging from 1 (not important) to 5 (very important). The sample consisted of 21 completed surveys involving successful IPOs from the period of 2007-2009

\begin{tabular}{|c|c|c|c|c|c|c|c|c|c|}
\hline & \multicolumn{8}{|c|}{$\begin{array}{c}\text { Survey Responses } \\
\text { IPO Status - Successful (Companies in Group A) } \\
\end{array}$} \\
\hline & & Mean & Median & Mode & Mode Frequency & Standard Deviation & $\% 1-2$ & $\% 3$ & $\% 4-5$ \\
\hline $\mathrm{a}$ & Raising external capital & 4,86 & 5,00 & 5,00 & 19 & 0,48 & 0.00 & 4,76 & 95,24 \\
\hline $\mathrm{h}$ & Publicity, image enhancement & 4,00 & 4,00 & 5,00 & 9 & 1,10 & 4,76 & 28,57 & 66,67 \\
\hline $\mathrm{k}$ & Acquisitions and mergers & 3,81 & 4,00 & 4,00 & 11 & 1,08 & 14,29 & 9,52 & 76,19 \\
\hline $\mathrm{c}$ & Stronger bargaining position & 3,71 & 4,00 & 4,00 & 9 & 1,10 & 14,29 & 19,04 & 66,67 \\
\hline $\mathrm{i}$ & Attractiveness as an employer & 3,71 & 4,00 & 4,00 & 8 & 1,06 & 9,52 & 28,57 & 61,91 \\
\hline $\mathrm{j}$ & Market value establishment & 3,71 & 4,00 & 4,00 & 8 & 1,06 & 9,52 & 28,57 & 61,91 \\
\hline $\mathrm{d}$ & Reducing the cost of capital & 3,05 & 3,00 & 2,00 & 6 & 1,24 & 38,10 & 23,80 & 38,10 \\
\hline $\mathrm{e}$ & Equity portfolio diversification & 2,76 & 3,00 & $\begin{array}{l}1,00 \\
2,00\end{array}$ & $\begin{array}{l}5 \\
5\end{array}$ & 1,41 & 47,62 & 19,05 & 33,33 \\
\hline $\mathrm{b}$ & Reducing company indebtedness & 2,38 & 2,00 & 1,00 & 7 & 1,40 & 61,90 & 19,05 & 19,05 \\
\hline $\mathrm{f}$ & Exit of venture capitalists & 1,95 & 1,00 & 1,00 & 13 & 1,56 & 80,95 & 0,00 & 19,05 \\
\hline $\mathrm{g}$ & Solving the problem of succession & 1,38 & 1,00 & 1,00 & 15 & 0,67 & 90,48 & 9,52 & 0,00 \\
\hline
\end{tabular}

Table 3

Survey Results - Reasons for Conducting IPO (Subsample B)

Means are based on a five-point scale ranging from 1 (not important) to 5 (very important). The sample consisted of 18 completed surveys involving sufficiently large companies that did not execute an IPO in the years 2007-2010

\begin{tabular}{|c|c|c|c|c|c|c|c|c|c|}
\hline & \multicolumn{8}{|c|}{$\begin{array}{c}\text { Survey Responses } \\
\text { IPO Status - Not Tried (Companies in Group B) }\end{array}$} \\
\hline & & Mean & Median & Mode & Mode Frequency & Standard Deviation & $\%$ 1-2 & $\% 3$ & $\%$ 4-5 \\
\hline $\mathrm{a}$ & Raising external capital & 4,44 & 5,00 & 5,00 & 10 & 0,70 & 0,00 & 11,11 & $\mathbf{8 8 , 8 9}$ \\
\hline $\mathrm{j}$ & Market value establishment & 3,65 & 4,00 & 4,00 & 9 & 0,86 & 11,76 & 23,53 & 64,71 \\
\hline $\mathrm{h}$ & Publicity, image enhancement & 3,61 & 4,00 & 4,00 & 7 & 1,20 & 11,11 & 27,78 & 61,11 \\
\hline $\mathrm{d}$ & Reducing the cost of capital & 3,41 & 4,00 & 4,00 & 8 & 0,94 & 11,76 & 35,29 & 52,94 \\
\hline $\mathrm{c}$ & Stronger bargaining position & 3,22 & 3,00 & 3,00 & 8 & 0,73 & 16,67 & 44,44 & 38,89 \\
\hline $\mathrm{i}$ & Attractiveness as an employer & 3,11 & 3,00 & 3,00 & 7 & 1,08 & 22,22 & 38,89 & 38,89 \\
\hline $\mathrm{b}$ & Reducing company indebtedness & 3,00 & 3,00 & 3,00 & 8 & 0,77 & 27,78 & 44,44 & 27,78 \\
\hline $\mathrm{k}$ & Acquisitions and mergers & 2,83 & 3,00 & 3,00 & 10 & 0,99 & 27,78 & 55,56 & 16,67 \\
\hline$f$ & Exit of venture capitalists & 2,38 & 2,00 & 2,00 & 6 & 1,20 & 61,11 & 11,11 & 27,78 \\
\hline $\mathrm{e}$ & Equity portfolio diversification & 2,33 & 2,00 & 2,00 & 7 & 1,03 & 61,11 & 22,22 & 16,67 \\
\hline $\mathrm{g}$ & Solving the problem of succession & 1,88 & 1,00 & 1,00 & 10 & 1,23 & 72,22 & 16,67 & 11,11 \\
\hline
\end{tabular}


Table 4

Survey Results - A Comparison between Subsamples

Means are based on a five-point scale raging from 1 (not important) to 5 (very important). The sample consisted of 39 completed surveys involving 21 successful IPOs in the period of 2007-2009, and 18 companies that were sufficiently large but did not execute IPO in the years 2007-2010. The p-values indicate simultaneous differences using the Mann-Whitney U-test. The values printed in bold are significantly different

\begin{tabular}{|c|c|c|c|c|c|c|c|c|c|}
\hline & & \multicolumn{3}{|c|}{ Overall } & \multicolumn{5}{|c|}{ IPO Status } \\
\hline & & \multirow{2}{*}{$\begin{array}{c}\text { Mean } \\
\text { (Median) }\end{array}$} & \multirow{2}{*}{$\begin{array}{l}\text { Standard } \\
\text { Deviation }\end{array}$} & \multirow{2}{*}{$\begin{array}{c}\% \\
4-5\end{array}$} & \multicolumn{2}{|c|}{$\begin{array}{c}\text { Subsample A } \\
\text { (Successful) }\end{array}$} & \multicolumn{2}{|c|}{$\begin{array}{c}\text { Subsample B } \\
\text { (Not Tried) }\end{array}$} & \multirow{2}{*}{$\begin{array}{c}\text { p (Mann- } \\
\text { Whitney U- } \\
\text { Test) }\end{array}$} \\
\hline & & & & & $\begin{array}{c}\text { Mean } \\
\text { (Median) }\end{array}$ & $\begin{array}{c}\% \\
4-5\end{array}$ & $\begin{array}{c}\text { Mean } \\
\text { (Median) }\end{array}$ & $\begin{array}{c}\% \\
4-5\end{array}$ & \\
\hline $\mathrm{a}$ & Raising external capital & $4,67(5,00)$ & 0,62 & 92,31 & $4,86(5,00)$ & 95,24 & $4,44(5,00)$ & 88,89 & $\mathbf{0 , 0 1 9}$ \\
\hline $\mathrm{h}$ & Publicity, image enhancement & $3,82(4,00)$ & 1,14 & 64,10 & $4,00(4,00)$ & 66,67 & $3,61(4,00)$ & 61,11 & 0,302 \\
\hline $\mathrm{j}$ & Market value establishment & $3,68(4,00)$ & 0,96 & 61,54 & $3,71(4,00)$ & 61,91 & $3,65(4,00)$ & 64,71 & 0,755 \\
\hline $\mathrm{c}$ & Stronger bargaining position & $3,49(4,00)$ & 0,97 & 53,85 & $3,71(4,00)$ & 66,67 & $3,22(3,00)$ & 38,89 & 0,065 \\
\hline i & Attractiveness as an employer & $3,44(4,00)$ & 1,10 & 51,28 & $3,71(4,00)$ & 61,91 & $3,11(3,00)$ & 38,89 & 0,082 \\
\hline $\mathrm{k}$ & Acquisitions and mergers & $3,36(3,00)$ & 1,14 & 48,72 & $3,81(4,00)$ & 76,19 & $2,83(3,00)$ & 16,67 & $\mathbf{0 , 0 0 3}$ \\
\hline $\mathrm{d}$ & Reducing the cost of capital & $3,21(3,00)$ & 1,12 & 43,59 & $3,05(3,00)$ & 38,10 & $3,41(4,00)$ & 52,94 & 0,307 \\
\hline $\mathrm{b}$ & Reducing company indebtedness & $2,67(3,00)$ & 1,18 & 23,08 & $2,38(2,00)$ & 19,05 & $3,00(3,00)$ & 27,78 & 0,048 \\
\hline $\mathrm{e}$ & Equity portfolio diversification & $2,56(2,00)$ & 1,25 & 25,64 & $2,76(3,00)$ & 33,33 & $2,33(2,00)$ & 16,67 & 0,384 \\
\hline $\mathrm{f}$ & Exit of venture capitalists & $2,15(2,00)$ & 1,41 & 23,08 & $1,95(1,00)$ & 19,05 & $2,38(2,00)$ & 27,78 & 0,119 \\
\hline $\mathrm{g}$ & Solving the problem of succession & $1,62(1,00)$ & 0,99 & 5,13 & $1,38(1,00)$ & 0,00 & $1,88(1,00)$ & 11,11 & 0,204 \\
\hline
\end{tabular}

Theories and Survey Conclusions

Table 5

\begin{tabular}{|c|c|c|c|c|}
\hline \multirow{2}{*}{\multicolumn{2}{|c|}{ Theories }} & \multicolumn{3}{|c|}{ Survey Evidence } \\
\hline & & \multirow{2}{*}{$\begin{array}{c}\text { Overall } \\
\text { strong support } \\
\end{array}$} & \multirow{2}{*}{$\begin{array}{c}\begin{array}{c}\text { Subsample A } \\
\text { (Successful) }\end{array} \\
\text { strong support } \\
\end{array}$} & \multirow{2}{*}{$\begin{array}{c}\text { Subsample B (Not Tried) } \\
\text { strong support } \\
\end{array}$} \\
\hline A & Raising external capital (Ritter \& Welch, 2002; Paleari et al., 2006) & & & \\
\hline $\mathrm{H}$ & $\begin{array}{l}\text { Publicity, image enhancement (Maksimovic \& Pichler, 2001; Jezek, } \\
\text { 2004) }\end{array}$ & strong support & strong support & strong support \\
\hline $\mathbf{J}$ & Market value establishment (Ellingsen \& Rydqvist, 1997) & strong support & strong support & strong support \\
\hline I & Attractiveness as an employer (Haubrok, 2006) & strong support & strong support & moderate support \\
\hline $\mathrm{K}$ & Acquisitions and mergers (Brau \& Francis \& Kohers, 2003) & moderate support & strong support & low support \\
\hline $\mathrm{D}$ & Reducing the cost of capital (Scott, 1976; Modigliani \& Miller, 1963) & moderate support & moderate support & strong support \\
\hline $\mathrm{B}$ & Reducing company indebtedness (Paleari et al., 2006) & low support & low support & moderate support \\
\hline $\mathrm{E}$ & Equity portfolio diversification (Pagano, 1993) & low support & low support & low support \\
\hline $\mathrm{F}$ & Exit of venture capitalists (Black \& Gilson, 1998) & low support & low support & low support \\
\hline $\mathrm{G}$ & $\begin{array}{l}\text { Solving the problem of succession (Black \& Gilson, 1998; Mello \& } \\
\text { Pardone, 1998) }\end{array}$ & low support & low support & low support \\
\hline
\end{tabular}

In addition, Table 5 compares theories or concepts and survey conclusions within the studied subsamples and represents a basis for summarized findings on what the survey results confirm and deny in the concluding part of this paper. In the first column, we list the theory, in the second column, we summarize the overall survey results and finally, in the third a fourth column, we assign a value of strong support, moderate support or low support within the subsamples.

\section{Analysis of Statistically Significant Dependencies}

In addition to the descriptive analysis of the collected data (presented in Tables 2-4), it is appropriate to include the analysis of statistically significant dependencies between the respondents' answers and the individual parts of the questionnaire.

Hypothesis: There is a correlation between the reasons for IPO implementation listed in the questionnaire (Table 4). The authors assumed that the following correlations may exist: (c) and (d); (f) and (j); (c) and (h); (h) and (k); (h) and (i); (e) and (j).

The results of the M-V chi-square test in Group A of companies are as follows: In general, statistically significant correlations between the individual reasons for IPO implementation were not found (data not included). The only exception was a statistically significant difference when comparing the responses to the questions about strengthening of bargaining position with providers of external capital (c), and reducing the cost of capital (d) $\left(\chi^{2}=11.34 ; d f=4 ; p=0.023\right)$. Economic interpretation:

The companies that identified the strengthening of position in negotiations with providers of external capital as an important reason to implement IPO also mentioned the capital cost reduction as another important reason to enter a public capital market. The results of the $\mathrm{M}-\mathrm{V}$ chisquare test in Group B of companies are as follows:

Only one statistically significant difference was found, which was in comparing the answers to the questions about the strengthening of bargaining position with providers of external capital (c) and the image and publicity enhancement (h) $\left(\chi^{2}=12.29 ; d f=4 ; p=0.015\right)$. Economic interpretation: The companies that aspire to strengthen their negotiating position with providers of external capital also strive to enhance their image and publicity. 


\section{Conclusions}

The results of this survey indicate that the academic and theoretical approaches to IPO process are, in the conditions of the Polish capital market, generally well applicable. However, the respondents' observations also suggest that there is a need for additional information that would complement and refine the existing theoretical models of IPOs.

Raising external capital for further growth as a reason for IPO received a strong support from the respondents of both groups of companies (A - Successful and B - Not Tried). In this case, the empirical results are fully consistent with the theoretical approaches. The magnitude of significance attached to this reason indicates that companies tend to consider IPO in the expansion stage of their life cycle, which is a positive signal, especially for the investors. Excellent financial results are reflected in the pricing of the issue and the number of subscribed shares.

Other theories formulated for conditions of welldeveloped capital markets were likewise strongly supported. More than $50 \%$ of respondents in both groups believe that the entry of a company into the capital market will have a positive effect on its image and publicity. The ability to trade shares on the capital market is one of the signs of a competent corporate management. The companies whose shares are traded on a stock exchange are usually perceived as the most successful in their business branch. Most of the respondents also believe that IPO will improve company's valuation, strengthen the management's bargaining position in negotiations with providers of external capital, and increase the attractiveness of the company as an employer. Somewhat surprising is the finding that the respondents do not see debt reduction as a reason to enter the capital market, although literature puts a lot of weight on this particular notion (Paleari et al., 2006). Low level of support was also given to other reasons mentioned in the literature, such as withdrawal from the venture capital fund (Black \& Gilson, 1998), diversification of the existing shareholders' portfolios (Pagano, 1993), and solution to the succession problem (Black \& Gilson, 1998; Mello \& Pardone, 1998). This of course must be understood in the light of the market conditions wherein the survey was conducted. Capital cost reduction is among the reasons of medium importance. In the group of companies that have gone through IPO, one important reason for entering the stock exchange is the possibility of using the shares in future mergers and acquisitions. The newly issued shares thus allow the company to acquire, or to be acquired, especially in transactions covered by shares. By contrast, this reason received a decidedly low support in the group of companies that had not implemented IPO. It is not without interest that Brau \& Fawcett (2006) came to a similar conclusion in their investigation of this motivation.

A comparison of the theoretical approaches with the survey results demonstrates that the theoretical model of IPO process is, in principle, applicable to the conditions in the Polish capital market, while at the same time highlighting the existence of certain differences. The results of this survey made it possible to formulate new insights as contributions towards a better understanding of corporate financing strategies, particularly under the specific conditions of the CEE region.

The outcome of this survey suggests that its continuation would be appropriate. In a follow-up survey, the sample should include the companies pursuing IPO in other countries of the CEE region, or the companies that are potential candidates for IPO on these markets. The next question to research is what factors can withdraw IPO process. Another research question of next studies could deal with the impact of going public on the business performance and performance measurement system which reflects the internal and external environment. The theoretical background for the methodology development has been carried out in the studies by e.g. Gimzauskiene \& Kloviene (2011) and Kocmanova \& Simberova (2012).

\section{Acknowledgment}

This paper is supported by the Czech Science Foundation. Name of the Project: IPO Strategy - Specific Approaches in the CEE Region. Registration No. 13-38047S.

\section{References}

Black, B. S., \& Gilson, R. J. (1998). Venture capital and the structure of capital markets: Banks versus stock markets. Journal of Financial Economics, 47 (3), 243-277. http://dx.doi.org/10.1016/S0304-405X(97)00045-7

Boehmer, E., \& Ljungqvist, A. (2004). On the decision to go public: Evidence from privately held firms. Deutsche Bundesbank Discussion Paper Series 1: Economic Studies.

Brau, J. C., \& Fawcett, S. E. (2006). Initial Public Offerings: An Analysis of Theory and Practise. Journal of Finance, 61 (1), 399-436. http://dx.doi.org/10.1111/j.1540-6261.2006.00840.x

Brau, J. C., \& Francis, B., \& Kohers, N. (2003). The Choice of IPO versus Takeover: Empirical Evidence. Journal of Business, 76 (4), 583-612. http://dx.doi.org/10.1086/377032

Chemmanur, T. J., \& Fulghiery, A. (1999). Theory of the Going-Public Decision. Review of Financial Studies, 12 (2), 249-279. http://dx.doi.org/10.1093/rfs/12.2.249

Chen, B. \& Liou, F. M., \& Huang, C. P. (2012). Optimal Financing Mix of Financially Non-Viable Private-Participation Investment Project with Initial Subsidy. Inzinerine Ekonomika-Engineering Economics, 23 (5), 452-461. 
Ellingsen, T., \& Rydqvist, K. (1997). The Stock Market as a Screening Device and the Decision to Go Public. Stockholm: Stockholm School of Ecnomics, Working Paper Series in Economics and Finance 174.

Gimzauskiene, E., \& Kloviene, L. (2011). Performance Measurement System: Towards an Institutional Theory. Inzinerine Ekonomika-Engineering Economics, 22 (4), 338-344.

Helwege, J., \& Packer, F. (2003). The Decision to Go Public: Evidence from Mandatory SEC Filings by Private Firms, Charles A. Dice Center for Research in Financial Economics Working Papers.

Haubrok, A. (2006). Der Börsengang als Finanzierungsalternative. Wiesbaden: Betriebswirtschaftlicher Verlag Dr. Th. Gabler.

Jezek, T. et al. (2004). Jak emitovat akcie a dluhopisy na kapitálovém trhu. KCP. Available from internet: http://ftp.pse.cz/Info.bas/Cz/NXT_KCP_IPO_final.pdf

Kocmanova, A., \& Simberova, I. (2012). Modelling of Corporate Governance Performance Indicators. Inzinerine Ekonomika-Engineering Economics, 23 (5), 485-495.

Maksimovic, V., \& Pichler, P. (2001). Technological innovation and initial public offerings. Review of Financial Studies, 14, 459-494. http://dx.doi.org/10.1093/rfs/14.2.459

Mello, A. S., \& Pardone, J., E. (1998). Going Public and the Ownership Structure of the Firm. Journal of Financial Economics, 49, 79-109. http://dx.doi.org/10.1016/S0304-405X(98)00018-X

Modigliani, F., \& Miller, M. (1958). The Cost of Capital, Corporation Finance and the Theory of Investment. American Economic Review, 53 (3), 433-43.

Modigliani, F., \& Miller, M. (1963). Corporate Income Taxes and the Cost of Capital: a Correction. American Economic Review, 48, 261-297.

Myers, S. C. (1984). The capital structure puzzle. Journal of Finance, 39, 575-592. http://dx.doi.org/10.1111/j.15406261.1984.tb03646.x

Norvaisiene, R. (2012). The Impact of Capital Structure on the Performance Efficiency of Baltic Listed Companies. Inzinerine Ekonomika-Engineering Economics, 23 (5), 505-516.

Pagano, M., \& Panetta, F., \& Zingales, L. (1998). Why do companies go public: An empirical analysis. Journal of Finance, 53, 27-64. http://dx.doi.org/10.1111/0022-1082.25448

Pagano, M. (1993). The flotation of companies on the stock market: a coordination failure model. European Economic Review, 37 , 1101-1125. http://dx.doi.org/10.1016/0014-2921(93)90111-M

Paleari, S. et al. (2006). Academic EurIPO Fact Book 2006. Bergamo: Universoft.

Paleari, S. et al. (2007). Academic EurIPO Fact Book 2007. Bergamo: Universoft.

Paleari, S. et al. (2008). Academic EurIPO Fact Book 2008. Bergamo: Universoft.

Paleari, S. et al. (2009). Academic EurIPO Fact Book 2009. Bergamo: Universoft.

Paleari, S. et al. (2010). Academic EurIPO Fact Book 2010. Bergamo: Universoft.

Rajan, R. G. (1992). Insiders and Outsiders: The Choice between Informed and Arm's Length Debt. Journal of Finance, 47 (4), 1367-4000. http://dx.doi.org/10.1111/j.1540-6261.1992.tb04662.x

Ritter, J. R., \& Welch, I. (2002). A review of IPO activity, pricing, and allocations. Journal of Finance, 57 (4), 1795-1828. http://dx.doi.org/10.1111/1540-6261.00478

Scott, J. H. (1976). A theory of optimal capital structure. The Bell Journal of Economics, 7 (1), $33-54$. http://dx.doi.org/10.2307/3003189

Snieska, V., \& Venckuviene, V. (2011). Hybrid Venture Capital Funds in Lithuania: Motives, Factors and Present State of Development. Inzinerine Ekonomika-Engineering Economics, 22 (2), 157-164.

Tomáš Meluzín, Marek Zinecker

IPO įdiegimo priežastys: Lenkijos kapitalo rinkos empirinio tyrimo rezultatai

Santrauka

Paskutinis dešimtmetis tapo svarbiu vertinant/ aptariant pasaulinị įmonių plètros finansavimo didejjimą per „Pirminius viešuosius siūlymus“ (angl. Initial Public Offering - IPO). İmonių finansų teorija (IPO), įdiegimo strategiją laiko vienu iš svarbiausių momentų, lemiančių kompanijos gyvavimą (Helwege ir Packer, 2003; Brau ir Francis ir Kohers, 2003; Boehmer ir Ljungqvist, 2004). Pirmiausia yra susiduria su motyvacijos veiksniu, kam pirmą karta viešai pasiūlyti akcijas. Pagrindiniai veiksniai, kurie daro itaka priimant sprendimus, dèl pirma karta viešai pasiūlytu akciju, moksliniuose teoriniuose darbuose yra pateikiami/suskirstyti ị keturias grupes: lèšų iš išorès gavimas norint pradèti grynosios dabartinės vertès projektus (Chemmanur ir Fulghiery, 1999; Ritter ir Welch, 2002), ilgalaikio finansavimo šaltinio ịsigijimas emitentų požiūriu (Pagano ir kt., 1998; Black ir Gilson, 1998), akcijų dalies sumažinimas kompanijoje (Zingales, 1995; Balck ir Gilson, 1998) bei nefinansinių privalumų iš IPO įdiegimo ịsigijimas (Maksimovic ir Pichler, 2001; Ježek, 2004; Brau ir Fawcett, 2006). Literatūros apžvalgoje rašoma, kad tyrimas to, kas paskatina kompanijas pirmą kartą pasiūlyti akcijas viešai, jau turi nemažas tradicijas gerai išvystytose rinkose. Tačiau tas nepasakyta apie kitas šalis. Trūksta teorinių duomenų ir praktinès analizès (empirinių rezultatų) apie ịmones Centrinès ir Rytų Europos šalyse. Vienintelè kapitalo rinka Centrinès ir Rytų Europos šalių regione, kuri leidžia atlikti empirinius tyrimus, buvo pateikta iš Lenkijos. Varšuvos vertybiniu popieriu birža priklauso toms Europos vertybiniu popierių biržoms, kurios turi didžiausią skaičių užbaigtų IPO.

Šio darbo naujumą sudaro tai, kad pirmiausia dėmesys sutelkiamas į veiksnių analizę, kurie daro įtaką sprendimams: pirmą kartą viešai pasiūlyti akcijas Lenkijos kapitalo rinkos sąlygomis. Taigi, šio straipsnio tikslas yra išnagrinèti veiksnius, kurie daro ịtaką įmonių sprendimui pirmą kartą viešai 
pasiūlyti akcijas Lenkijos kapitalo rinkoje ir tokiu būdu papildyti/ suteikti trūkstamos informacijos, kurios nèra mokslinèje literatūroje, tiriant IPO apklausą ir nustatant pagrindinius kompanijų Lenkijoje motyvus, dẻl viešai siūlomų akcijų.

Tyrimo metodai: mokslinès literatūros, dokumentų ir ataskaitụ bei statistinių duomenų analizè. Siekiant šio tyrimo tikslo, buvo surinkti pirminiai duomenys. Pavyzdị sudaro dviejų tipų kompanijos. Tai reiškia, kad analizuojami du mažesni pavyzdžiai. Pirmaji, mažesniji pavyzdị sudaro subjektai, kurie prieš tai vykdè pradinị viešą siūlymą (Pavyzdys A - Sèkmingos). Antrą, mažesnį pavyzdị sudaro subjektai, kurie nevykdè IPO, bet nagrinèjo galimybę tai daryti anksčiau arba ketino tai daryti ateityje (Pavyzdys B - Nebandžiusios). Anketą sudare dvi dalys: priežastys vykdyti IPO ir priežastys išlaikyti privačią nuosavybę. Duomenys buvo surinkti dviejuose pagrindiniuose etapuose. 2010 metu pradžioje anketa buvo išsiųsta visoms A-tipo kompanijoms, esančioms tyrimo sąraše (iš viso 107 subjektai). Norint gauti kuo daugiau atsakymų, 2010 metų balandžio mènesi anketa buvo išsiųsta elektroniniu paštu tiems respondentams, kurie neatsake pirmaji kartą i prašymą užpildyti anketą. Iš viso, tinkamus vertinti atsakymus pateikẻ 21 finansinių tarnybų vadovas ( atsakymų norma yra 19,6 \%). 2011 metų rudenị, anketa su lydraščiu buvo išsiųsta visoms 60 grupès B kompanijų. Taip pat, norint gauti daugiau atsakymų, 2012 metu sausio mėnesị visiems respondentams elektroniniu paštu buvo išsiųstas pakartotinis prašymas dalyvauti apklausoje. Buvo gauta 18 užpildytų anketų. Tai sudare $30 \%$ atsakymų. Apklausos būdu surinkti duomenys buvo apdoroti statistiniais metodais, atspindinčiais jų prigimtị ir kiekị. Aprašomieji metodai leido juos išnagrinèti statistiškai. Kategoriniai duomenys buvo apdoroti panaudojant atsitiktinumo lenteles ir ịvertinti panaudojus M-V chi kvadrato testą, pakoreguotą/ pritaikytą individualių kategorijų mažam dažnumui. Buvo taikytas Mann-Whitney U-testas, norint palyginti statistinius duomenis tarp stebimų grupių. Duomenys buvo įvertinti reikšmingumo lygiu $\alpha=5 \%$. Apklausos rezultatus galima apibendrinti taip. Pirma, išorinio kapitalo didinimas tolesniam augimui, kaip priežastis vykdyti IPO, gavo didelę respondentų paramą abiejose kompaniju grupese (A - Sékmingos ir B - Nebandžiusios). Šiuo atveju, empiriniai rezultatai visiškai atitinka teorinius metodus. Šiai priežasčiai priskirto reikšmingumo dydis rodo, kad kompanijos yra linkusios svarstyti ar vykdyti IPO jų gyvavimo ciklo plètimosi metu. Tai yra teigiamas ženklas, ypač investuotojams. Antra, daugiau nei 50\% abiejų grupių respondentų tiki, kad IPO strategija turès teigiamą ịtaką jų ịvaizdžiui ir viešumui. Kompanijos, kurių akcijomis prekiaujama akcijų biržoje, dažniausi suvokiamos kaip sėkmingiausios kompanijos savo verslo šakoje. Trečia, dauguma respondentų taip pat tiki, kad IPO pagerins kompanijos vertinima, sustiprins vadovybès derybines pozicijas derybose su išorinio kapitalo tiekejais ir padidins kompanijos, kaip darbdavio, patrauklumą. Toliau, šiek tiek stebina rezultatas, kad respondentai nevertina skolos sumažinimo, kaip priežasties vykdyti IPO, nors teorijose teikiama daug reikšmès kalbant apie šią konkrečią sąvoką (Paleari ir kt., 2006). Mažai paramos gavo kitos literatūroje paminètos priežastys, pvz., pasitraukimas iš rizikos kapitalo fondo (Black ir Gilson, 1998), esamu akcininku portfeliu diversifikacija (Pagano, 1993) ir paveldèjimo problemos sprendimas (Black ir Gilson, 1998; Mello ir Pardone, 1998). Kapitalo kaštų sumažinimas yra tarp vidutinès svarbos priežasčiu. Galiausiai, kompanijų, kurios viešai pardave akcijas, viena iš svarbiu priežasčių vykdyti IPO, yra galimybe panaudoti akcijas būsimiems įmoniu susijungimams ir ịsigijimams. Taigi, naujai išleistos akcijos leidžia kompanijai ịsigyti arba būti ̨̧sigytai, ypač per sandorius, padengtus akcijomis. Ši priežastis buvo vertinama prastai tų kompanijų grupès, kurios neįdiegè IPO. İdomu tai, kad Brau ir Fawcett (2006) priëjo panašią išvadą, atlikdami šios motyvacijos tyrimą.

Toliau apdorojant duomenis, buvo siekiama nustatyti ar egzistuoja statistiškai reikšmingi skirtumai tarp respondentu atsakymu dažnumu tirtose kompanijų grupèse (Grupė A - IPO kompanijos, ir Grupè B - Nebandžiusios kompanijos). M-V chi kvadrato testo ir Mann-Whitney U-testo rezultatai parode statistiškai reikšminga skirtumą tarp atsakymu i „akciju, kuriomis prekiaujama vieša panaudojimą vėlesniems susijungimams ir ịsigijimams“ dažnį. Mann-Whitney U-Testo rezultatai taip pat nustatè/ atskleidè statistiškai reikšmingus skirtumus tarp dviejų kompaniju grupių. Jos buvo analizuojamos su kitomis dviem priežastimis dèl IPO vykdymo, kurių nepatvirtino M-V chi kvadrato testas ( būtent kompanijos skolos sumažinimo ir akcijų, kuriomis prekiaujama viešai, panaudojimu vėlesniems susijungimams ir ịsigijimams, testas).

Statistiškai reikšmingų priklausomybių, tarp respondentų atsakymų ir individualių anketos dalių analizė rodo, kad egzistuoja statistiškai reikšmingas skirtumas (lyginant atsakymus ị klausimus apie derybu poziciją, derantis su išorinio kapitalo tiekẻjais dèl stiprinimo ir kapitalo kaštu mažinimo) grupẻje A. Taigi, kompanijos, kurios nurode pozicijas stiprinti derybas su išorinio kapitalo tiekẻjais diegiant IPO, taip pat paminèjo ir kapitalo kaštų mažinimą, kaip kitą svarbią priežastį patekti ị viešojo kapitalo rinką. Grupèje B buvo atrastas kitas, statistiškai reikšmingas skirtumas, kuris buvo pastebètas lyginant atsakymus ị klausimus apie derybinių pozicijų stiprinimą, derantis su išorinio kapitalo tiekèjais. Kompanijos, kurios bando stiprinti savo derybines pozicijas derybose su išorinio kapitalo tiekejais, taip pat siekia sustiprinti savo ịvaizdị ir viešumą.

Teoriniu metodụ palyginimas su apklausos rezultatais parodo, kad teorinis IPO proceso modelis, iš esmès, gali būti taikomas Lenkijos kapitalo rinkos sąlygomis, tuo pačiu metu pabrěžiant/ nurodant tam tikrų skirtumų egzistavimą. Šios apklausos rezultatai leido suformuluoti naujas ižvalgas, kurios yra svarbios geriau suprantant įmonių finansavimo strategijas, ypač esant tam tikroms sąlygoms Centrinès ir Rytų Europos regione.

Raktažodžiai: įmoniu finansai, finansiniai sprendimai, IPO, kapitalo rinka, Lenkija.

The article has been reviewed.

Received in February, 2013; accepted in June, 2014. 